引用格式:龚荣发,曾维忠. 政府推动背景下森林碳汇项目农户参与的制约因素研究 [J]. 资源科学, 2018,40(5): 1073-1083. [Gomg R F, Zeng W Z. Factors restricting the participation of farmers in Forest Carbon Sequestration Projects[J]. Resources Science, 2018,40(5) : 1073-1083.] DOI :10.18402/resci.2018.05.19

\title{
政府推动背景下森林碳汇项目农户参与的制约 因素研究
}

\author{
龚㭉发 ${ }^{1}$, 曾维忠 ${ }^{1,2}$
}

(1. 四川农业大学经济学院,成都 $611130 ; 2$. 西南减贫与发展研究中心,成都 611130)

\begin{abstract}
摘 要: 本文以四川省 2 个典型森林碳汇项目区 $670 户$ 参与农户为样本, 基于嵌入式社会结构理论, 利用结构 方程模型对森林碳汇项目农户参与程度进行分析, 研究发现: 农户营林造林技术落后难以满足碳汇林建设、林地准 入标准严格限制大量林地资源投入、社区非正式组织功能弱化而正式组织发展不足是导致农户参与程度较低的 3 个主要原因。因而,提升农户营林造林技术、降低林地准入标准、推动林业类合作社等社区正式组织发展是提升农 户参与程度的重要措施。当然, 林地面积、劳动力以及收入水平等资源禀赋和社会资本也是影响农户参与程度的 重要方面。
\end{abstract}

关键词: 森林碳汇项目; 参与程度; 嵌入式社会结构理论; 结构方程模型

DOI :10.18402/resci.2018.05.19

\section{1 引言}

近年来, 伴随后京都时代的来临及其《巴黎路线 图》(2007年)、《哥本哈根协议》(2009年)与《巴黎协 定》(2015年)等一系列国际协定的签订,森林碳汇 适应与减缓气候变化以及减贫的作用更加凸显 ${ }^{[1,2]}$, 基于国际森林碳汇交易稳步上升, 国内“京都规则” 和“非京都规则”的碳汇造林再造林项目试点的深 人 $^{[2,3]}$, 有关森林碳汇项目农户参与的研究, 成为近 年来国内外研究中普遍关注的议题之一, 众多研究 结果表明,农户参与是森林碳汇项目顺利实施的必 要条件,也是项目长期 (一般 20 40 年) 可持续运营 的重要保障 ${ }^{[4-7]}$ 。尤其是伴随着均山到户林权政策 的全面实施,农户逐渐成为森林碳汇项目最主要的 供给者 ${ }^{[8]}$ 和最直接参与者 ${ }^{[9]}$, 碳汇建设、经营和交易 都离不开农户参与, 农户参与行为直接影响森林碳 汇项目的顺利开展 ${ }^{[8,10]}$ 和森林碳汇交易实施 ${ }^{[1]}$ 。虽
然目前森林碳汇项目以政府推动型为主,存在着农 户非自主选择,但农户对项目的配合程度以及部分 自主选择下的参与决策仍然是影响森林碳汇可持 续发展的重要方面 ${ }^{[4,5]}$, 提升农户参与性对推动已有 项目发展和新项目开发仍具有显著意义。

国内外众多文献针对农户参与现状和参与意 愿进行了广泛的研究, 鉴于发展动机、模式以及自 然条件等方面的差异, 国外学者认为劳动力、土地、 资金等资源禀赋和碳税、补偿以及市场交易成本等 外部因素是影响农户参与的重要方面 ${ }^{[12-15]}$ 。国内学 者则集中于内部因素的探讨,主要涉及三个方面： 一是户主或具有决策权的家庭成员的个体特征,性 别、年龄、受教育程度以及对森林碳汇的认知程度 等都对农户参与意愿具有显著的影响 ${ }^{[8,9,16]}$; 二是家 庭经营特征, 即林地面积、收人水平、劳动力结构等 资源禀赋, 主流的观点认为, 资源禀赋越高, 参与意

收稿日期: 2017-09-05 修订日期: 2018-01-01

基金项目:国家社会科学基金项目(15BJY093);四川省软科学研究计划项目(2015ZR0031);四川省教育厅高等学校人文社科重点研究基地 一西南减贫与发展研究中心资助(SCP1609)。

作者简介 龚荣发,男,重庆奉节人,博士生,主要研究方向林业经济与资源管理。E-mail: YIrfs2014@163.com

通讯作者 :曾维忠,E-mail: 1069586776@qq.com

http://www.resci.cn 
愿和参与能力越大 ${ }^{[8,9]}$; 三是对森林碳汇收益、损失 和风险的预期 (感知), 农户从森林碳汇中获益越 高、森林碳汇实施越容易、对农户原有农业生产影 响越小, 农户参与意愿越高 ${ }^{[17,18]}$ 。也有部分学者开 始关注政府行为和项目特征对农户参与的影响, 明 辉认为, 与林业部门和集体组织的关系是影响农户 参与的重要因素 ${ }^{[8]}$; 杨帆认为项目组织模式直接影 响农户获益能力, 进而影响农户可持续参与决策 ${ }^{[9]}$ 。

已有成果对本研究有重要价值和启示, 但绝大 多数研究都单纯地从农户或家庭内部因素出发, 忽 略了当前森林碳汇项目以政府推动为主这一前提, 在当前中国基层治理制度和碳市场发展背景下, 地 方政府或者说村社集体依然是森林碳汇项目发展 的主要推动者, 将政府行为、项目特征等外部因素 纳人农户参与行为分析是必要的; 其次, 参与意愿 只是影响参与行为的一个方面, 尤其是在政府推动 背景下, 政府行为和项目特征会扭曲参与意愿对参 与行为的影响, 因而参与意愿不是农户参与性的最 佳反映; 最后, 以往研究忽略了社会资本对农户参 与行为的影响。为此, 本文试图借鉴嵌人式社会结 构理论, 通过微观抽样调查数据, 以参与程度为对 象, 实证研究在既定 CDM 森林碳汇标准下, 项目实 施区域农户森林碳汇参与行为及其影响因素, 以期 能为扫清或减少农户参与障碍, 制定提升农户参与 性的森林碳汇支持政策提供有益借鉴。

\section{2 理论基础与分析框架}

嵌人式社会结构理论认为, 经济行动不是完全 原子化和孤立的,而是嵌人于社会结构中的,其受 到社会关系的制约,任何一项经济行为, 都受到自 主因素和嵌人因素的双重约束。森林碳汇农户参 与行为不仅受到农户个体特征、家庭资源禀赋、社 会资本等自主因素的影响, 还受到嵌人因素的制 约, 包括森林碳汇项目组织模式、产权归属等项目 特征和项目属地经济发展、村民和睦程度等村社环 境特征。首先, 家庭联产承包责任制下家庭仍是农 业生产经营决策的主体, 尤其是集体林权制度改革 逐步深化背景下,农户或家庭的森林碳汇供给主体 地位逐步得到体现和提升, 户主的文化程度、性别 等个体特征以及家庭资源禀赋、社会资本等家庭特 征均会通过影响参与意愿和参与能力, 进而影响农
户参与决策和参与行为。其次, 中国长期以来实行 的家庭联产承包责任制导致农村土地细碎分散，而 森林碳汇要求规模化集中生产, 这就导致单一农户 不可能独自进行森林碳汇供给, 不可避免地受到项目 属地政府、集体、其他农户行为和经济、社会、自然 环境的影响。最后, 中国基层治理制度决定了地方 政府或村社集体在森林碳汇项目建设中突出作用, 尤其是目前中国碳交易市场尚不完备的情况下,在 未来一段时期内,政府依然是森林碳汇项目主要的 推动力量, 在这一背景下, 农户参与行为涉及两个 主要的方面:一是非自主选择下的配合行为,二是 自主选择下的参与决策。因而本文借鉴嵌人式社 会结构理论,探讨农户个体特征、家庭经营特征、家 庭社会资本特征 3 个自主因素, 项目特征和社区特 征 2 个嵌人因素对森林碳汇农户参与程度的影响。

（1）“自主因素”中的农户个体特征是指户主或 家庭决策者的文化程度、年龄、性别等会对森林碳 汇认知程度、参与意愿、参与决策等产生影响力的 因素。本文选择文化程度、性别与年龄作为农户个 体特征的描述。

(2)“自主因素”中的家庭经营特征是家庭所拥 有的劳动力、林地、经济收人等会对森林碳汇参与 方式、参与程度等产生影响力的因素。本文选用收 人水平、劳动力结构与林地面积来反映经营特征。

（3）“自主因素”中的家庭社会资本特征是家庭 所拥有的关系网络、社会信任等会对森林碳汇项目 决策、建议、监测评估等信息的知情权产生影响力的 因素。本文选用农户家庭关系网络、对政府的信任 程度以及村民之间的相互信任程度作为二级指标。

(4) “嵌人因素” 中的社区特征: 森林碳汇项目 的生产成本、项目的注册、管理等都由项目属地政 府或第三方企业承担,因而农户参与程度不可避免的 受到项目属地政治、经济、自然环境特征的影响。 本文选用畜牧业依赖程度、政府对森林碳汇的支持 程度以及社区之间的融洽程度来反映社区特征。

(5)“嵌人因素”中的项目特征主要是指森林碳 汇项目劳动力投人、林地来源、组织模式等会影响 影响农户参与方式、利益联结机制、收益风险保障 以及对自身权利、义务的认知的因素。本文依据实 际, 选用劳动力来源、碳汇林地权属以及组织模式 
作为项目特征的二级指标。

参与程度的高低主要取决于参与意愿和参与 能力两个方面, 因而自主因素和嵌人因素对森林碳 汇农户参与程度的影响,包括两条路径:一是通过 影响农户参与意愿, 间接影响农户参与程度;已有 研究表明,农户个体特征、家庭经营特征等自主因 素对农户参与意愿具有显著的影响 ${ }^{[8,916]}$; 而政府行为、 项目模式等嵌人因素会影响农户对森林碳汇的利 得和风险预期,进而影响参与意愿 ${ }^{[19]}$ 。二是直接对 农户参与行为形成 “控制”, 影响农户参与能力 ${ }^{[19]}$ 。 因而本文将参与意愿作为中间变量,一方面全面分 析自主因素和嵌人因素对参与程度的影响, 另一方 面分析在当前政府推动背景下,农户自主选择的高 低。影响路径如图 1所示。

\section{3 研究方法与数据来源}

\section{1 研究方法}

农户参与程度的研究最先主要集中在社会治 理、基层民主等政治参与方面 ${ }^{[20]}$,伴随着态度-行为 理论的发展, 人们对参与意愿和参与程度差异的认 识加深, 农户参与程度的研究也逐步拓展到农村信 贷 ${ }^{\left[{ }^{[2]} 、\right.}$ 农村养老保险 ${ }^{[22]}$ 等政策参与和农地整理、城乡 建设用地增减挂钩等项目参与领域, 尤其是项目参 与程度, 汪文雄、何钊认为项目参与程度是项目各 个阶段 “需要”农户参与的各类活动所对应的农户 实际行为的集合 ${ }^{[23,24]}$ 。据此,本文认为, 森林碳汇项 目农户参与程度是指在森林碳汇项目规划设计、组 织建设和监测评估 3 个阶段,需要农户配合或参与 的 9 项活动中农户实际行为的综合反映 (见表 1 )。

结合本文变量特征、数据类型以及研究目的,

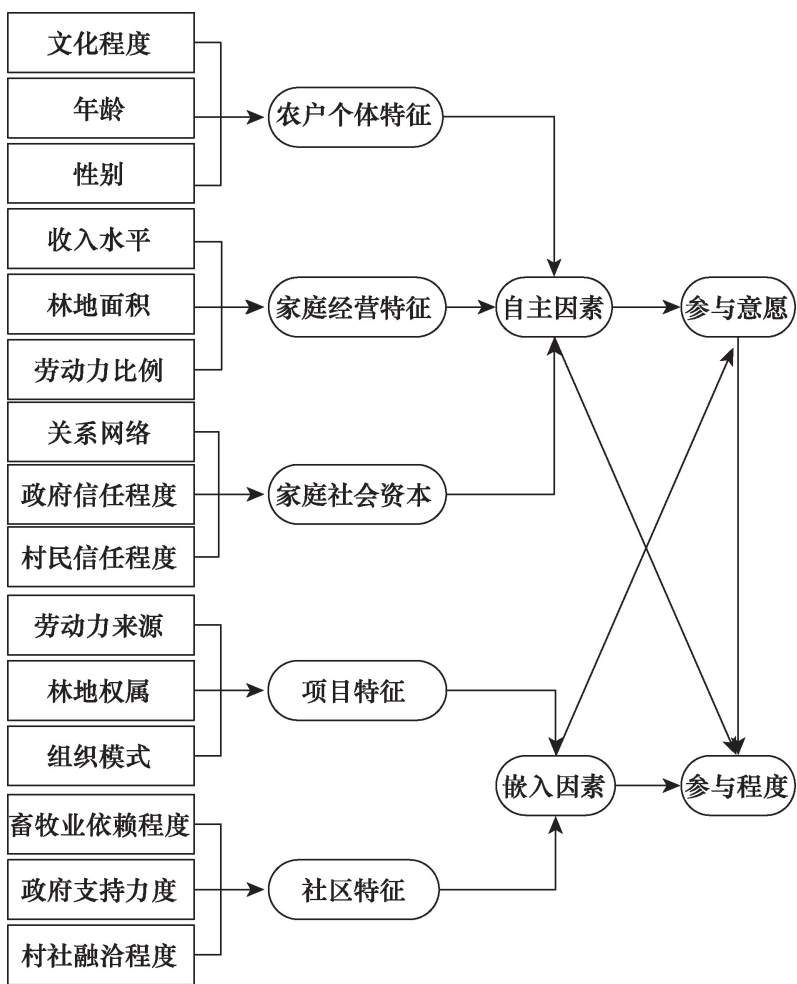

图 1 森林碳汇项目农户参与程度分析框架

Figure 1 Framework for analysis of farmers' participation in forest carbon sequestration projects

选用结构方程模型, 以个体特征、家庭特征、社区环 境、项目特征、参与意愿为潜变量, 通过设置相应的 可测变量来分析参与程度的影响因素。首先, 本文 研究涉及的农户个体特征、家庭经营特征、家庭社 会资本特征、项目特征、社区特征、参与意愿以及参 与程度 7 个变量, 难以用单一指标来准确度量, 往往 是多种行为或多个方面的综合反映。其次,本文涉 及的指标大多为农户主观评价, 从数据类型上来 看, 主要是 1 5 的离散分布。最后,本文研究的目的

表 1 农户参与程度内容及量化

Table 1 Content and quantitative table of farmers' participation

\begin{tabular}{|c|c|c|}
\hline 参与阶段 & 参与行为 & 指标量化 \\
\hline \multirow[t]{2}{*}{ B1: 规划设计阶段 } & B11:是否参加或知晓本底调查(问卷、座谈等) & 是 $=1$; 否 $=0$ \\
\hline & B12:是否就规划设计提出自己或村民代表的意见 & 是 $=1$; 否 $=0$ \\
\hline \multirow[t]{5}{*}{ B2: 组织建设阶段 } & B21:是否公示(公告)项目规划或签订合同 & 是 $=1$; 否 $=0$ \\
\hline & $\mathrm{B} 22$ :是否参与培训 & 是 $=1$; 否 $=0$ \\
\hline & B23:是否取得宜林地人股或流转收益 & 是 $=1$; 否 $=0$ \\
\hline & B24:是否取得劳务、管护、放牧和公益林生态补偿等收益 & 是 $=1$; 否 $=0$ \\
\hline & B25:是否遵守合同 & 是 $=1$; 否 $=0$ \\
\hline \multirow[t]{2}{*}{ B3:监测评估阶段 } & B31:是否参与项目阶段性验收、监测和评估 & 是 $=1$; 否 $=0$ \\
\hline & B32:避免矛盾和纠纷的意见是否被采纳 & 是 $=1$; 否 $=0$ \\
\hline
\end{tabular}


是探讨多个因变量对参与程度的影响, 且分析单一 变量对总影响的贡献以及变量之间的相互影响。

\section{2 数据来源}

本文数据来源于对森林碳汇项目区的实地调 查。为深人探讨农户参与程度, 科学、全面反映农 户参与行为, 课题组在走访四川省、凉山州各级林 业主管部门、四川省大渡河造林局、北京山水自然 保护中心成都办公室等多方项目参与主体基础上, 设计了调查问卷和访谈提纲, 并在 2015 年对茂县进 行预调研的基础上对问卷进行修正。基于研究需 要,课题组于 2015-2016年对 “中国四川西北部退 化土地造林再造林项目 (以下简称川西北项目)”和 “川西南林业碳汇、社区与生物多样性项目 (以下简 称川西南项目)” 2 个项目区开展了实地调查, 调查 以甘洛县和平武县 2 个县作为样本县, 在每个样本 县抽取 3 个村作为样本村, 对涉及的符合条件的 691 户农户进行问卷访问, 获得有效问卷 670 份 (Q312/ P358）, 问卷有效率 $96.96 \%$, 详细收集了自主因素、 嵌人因素、参与意愿和参与程度等 4 个层面的信息, 并对收集到的数据进行了标准化和分级处理, 以减 少数据量纲对研究结果的影响, 如户主年龄、家庭 林地面积和收人水平 3 个指标均采用对原始数据进 行标准化处理 ( (实际值-最小值) / (最大值-最小 值)), 再以 0.2 为间距划分为 $1 、 2 、 3 、 4 、 5$ 等 5 个等级 (本文其他可测变量以主观变量为主, 均采用李克 特 5 级指标量化, 为避免数据类型差异导致分析偏 差, 因而对将指标划分为 5 等级)。

\section{3 样本区域描述}

川西南项目和川西北项目均属于京都规则下 的造林再造林项目 (CDM/AR), 在土地合格性、碳基 线、边界以及碳汇计量监测标准、方法等方面一致,
项目实施区主要分布在偏远、贫困的民族区域,实 施主体均是大渡河造林局,但两者的组织经营模式 不同以及项目属地经济、社会、文化环境的差异, 导 致农户参与方式、参与意愿、参与程度差异化显著, 具体项目特征分析见表 2 。课题组在走访中发现： 川西北-平武县项目 (川西北项目平武县实施区) 是 由大渡河造林局自筹经费建设的单边项目 (先建设 后销售)，县林业局协助造林、管护，提供部分造林 种苗资金投人,并联合大渡河造林局和其他单位开 展造林技术培训、启动食用菌培育和生物质固体燃 料加工利用试验示范项目等惠民举措。碳汇造林 主要依托项目区当地或周边农户或造林施工队,项 目期结束后,农户获得全部木材收益和 30\%的碳汇 收益,林业局获得 $20 \%$ 的碳汇收益, 因而对项目的 支持力度较高, 协助项目所在村建立村规民约, 以 保证项目顺利开展，同时,大渡河造林局在碳汇林 区建立木制围栏,减少放牧和人类无意识行为破 坏。川西南-甘洛县项目 (川西南项目甘洛县实施 区)属于双边项目 (先销售后建设),前期资金主要 来源于诺华企业提前支付的部分碳信用,极大的减 缓了前期的资金压力, 为确保造林成活率和规范, 主要依托雷波造林公司开展造林,但农户参与项目 的方式和途径单一,农户获益能力较弱, 同时碳汇 林地主要由宜林荒山或轮歇地构成, 林牧矛盾突 出,农户对项目抵触情绪较高, 加上林业局属于辅 助单位, 不享受利益分配, 对项目积极性不高, 导致 农户对项目收益预期偏离较大。

\section{4 实证分析}

\section{1 描述性统计}

从综合参与占比来看, 甘洛县 $(26.34 \%)$ 和平武 县 $(30.03 \%)$ 农户参与程度普遍较低, 3 个阶段参与

表 2 川西北-平武县项目和川西南-甘洛县项目特征分析

Table 2 Feature analysis table on southwest and northwest of Sichuan Province

\begin{tabular}{cll}
\hline \multicolumn{1}{c}{ 川西南-甘洛县项目 } & \\
\hline 资金来源 & 诺华 $57 \%$; 政府配套 $43 \%$ & 川西北-平武县项目 \\
林地来源 & 以农户宜林荒山、轮歇地为主,部分集体林地 & 以村民小组集体林地为主,部分农户自留林地 \\
利益分配 & 木材收益 $100 \%$ 归农户; & 木材收益 $100 \%$ 归农户 ; 碳汇收益 $30 \%$ 归农户 , $25 \%$ 归大渡河造林局, \\
& 碳汇收益 $100 \%$ 归诺华 & $20 \%$ 归平武县林业局, 25\%用于经营管理支出 \\
经营管理 & 大渡河造林局统一管理;资业雇佣当地部分农户 & 大渡河造林局和平武县林业局管理; 平武县林业局雇请当地农户或护 \\
& 抚育管护 & 林员进行后期抚育管护 \\
造林主体 & 雷波造林公司,部分采用当地农户 & 当地造林施工队,并由保护区负责施工前技术培训,技术人员现场指导 \\
\hline
\end{tabular}


程度差异化明显, 监测评估阶段参与程度最低, 从 福利改善的角度来看, 相比于劳动力投人、林地投 人等能带来直接经济福利的参与行为, 建议权、知 情权等能带来非经济福利的参与行为参与程度相 对较低。甘洛县与平武县对比来看, 后者参与程度 相对高于前者, 且两者在各阶段各行为上存在明显 的差异, 尤其是 “是否参与培训” 和 “是否履行合同” 两项行为, 可能的原因是:一方面, 川西北项目由政 府主导, 开展多项惠农举措, 在农业生产技能培训 开展的频次、范围等方面相对较好, 且甘洛县属于 彝族聚集区，常年的牧耕文化使得农户对农业生产 技能的需求较弱。另一方面, 甘洛县对畜牧业的依 赖程度较高, 森林碳汇项目开展所形成的林牧冲突 较为严重, 导致农户参与意愿较低, 参与程度不 高。但值得关注的是, 甘洛县在农户间接参与方面 明显优于平武县, 这可能与平武县大量农民尤其是 青壮年普遍“离农”和“外出务工”有关。

调研对象中男性受访较多, 占样本总数的 $69.61 \%$; 受访农户年龄偏高, $61.49 \%$ 受访者在 45 岁 以上。甘洛县样本中彝族占比高 $(71.79 \%)$, 女性户 主比例较高 $(31.09 \%)$, 农业以放牧为主, 对林地的 依赖度较大, 林牧冲突明显, 文化程度相对较低, 大 部分农户仅受过 1 2 年教育, 收人水平较低; 碳汇林 主要以农户荒山荒地或轮歇地为主, 采用专业造林 公司进行碳汇林营造和管护, 对政府信任程度相对 较低,但村民之间信任程度较高; 对项目本地调查、 规划、监测评估等阶段间接参与的意愿较高, 但劳 动力和林地投人等直接参与意愿相对较低。平武 县样本中汉族居多, 文化程度相对较高, $96.09 \%$ 的 农户家庭中有小学水平以上的成员, 林地资源和劳 动力相对丰富, 家庭生产以农业和外出务工为主, 对牧业的依赖度较弱, 收人水平较高; 碳汇林以集 体林地为主, 项目属地农户劳动力投人占比较高 $(88.83 \%)$, 且享有部分碳汇收益, 对政府信任程度 较高, 农户直接参与和间接参与意愿较高, 甘洛, 平 武二地评价标准及描述性分析见表 3 。

\section{2 计量分析}

为检验问卷的稳定性和可靠性, 本文运用 SPSS20.0 对样本进行信度和效度检验, 整体克伦巴 赫 $\alpha$ 系数为 0.801 , 表明问卷具有较好的内部一致
性。因子分析结果表明, KMO 值为 0.802 , Bartlett 检验近似卡方为 2798.308 , 显著水平为 0.000 , 各解 释变量内部一致性较高, 旋转后累计方差贡献率较 高, 表明数据具有较好的结构效度。被解释变量克 伦巴赫系数为 0.572 (大于 0.5 ), 共提取 2 个有效因 子, 且分布与直接参与和间接参与一致, 说明将参 与行为划分为直接参与和间接参与同现实相吻 合。具体检验结果见表4(见第1079页)。

本文使用AMOS17.0 软件作为结构方程模型分 析的软件工具,利用川西北-平武和川西南-甘洛两 县 670 户数据进行整体样本的验证性分析, CFI 和 GFI 值均大于 0.90 , RESMA 小于 0.08 , 表明模型对 数据的拟合程度较高, 路径系数标准化结果如表 5 所示 (见第 1079 页)。

\section{3 实证结果分析}

结构模型分析表明,农户个体特征、家庭经营 特征、家庭社会资本等 5 个潜变量都直接影响或通 过参与意愿间接影响农户参与程度, 这与明辉等、 朱臻等、黄颖利等的研究一致 ${ }^{[8,16,19]}$ 。社区特征和项 目特征对参与程度的影响最大, 总影响效应为 1.154 和 1.031 , 表明农户能否或愿意参与项目, 不仅是一 个农户自主经济行为选择,也是项目属地政府和项 目业主主导下的管理选择,且更多的受到后者的影 响, 因而参与意愿对参与程度的影响系数相对较小 $(0.3570)$, 且路径显著性不高 $(P=0.1372)$, 进一步说 明参与程度研究的意义。但参与意愿在不同项目 区域内, 对参与程度的影响显著, 主要的原因在于, 两个项目农户自主选择行为的差异, 川西南-甘洛 项目碳汇林主要依赖于农户荒山荒地或轮歇地为 主,农户具有林地经营权, 因而在林地投人上具有 自主选择权。相反, 川西北-平武项目以集体林为 主,农户在林地投人上不具有自主选择权, 反而是 劳动力投人上具有自主选择权, 因而在不同项目下 参与意愿影响的参与行为的具体方面不同, 导致总 体上参与意愿影响不显著, 而同项目区影响显著。

从项目特征来看, 森林碳汇项目劳动力来源、 林地权属以及签约模式直接决定了农户参与到森 林碳汇的可能程度。川西南-甘洛项目为保证项目 造林符合 CDM标准, 采用专业造林公司负责造林, 限制了农户在劳动力上的投人, 因而川西南-甘洛 


\section{表 3 参与程度解释变量评价标准及描述性分析}

Table 3 Evaluation criteria and descriptive analysis of explanatory variables of participation

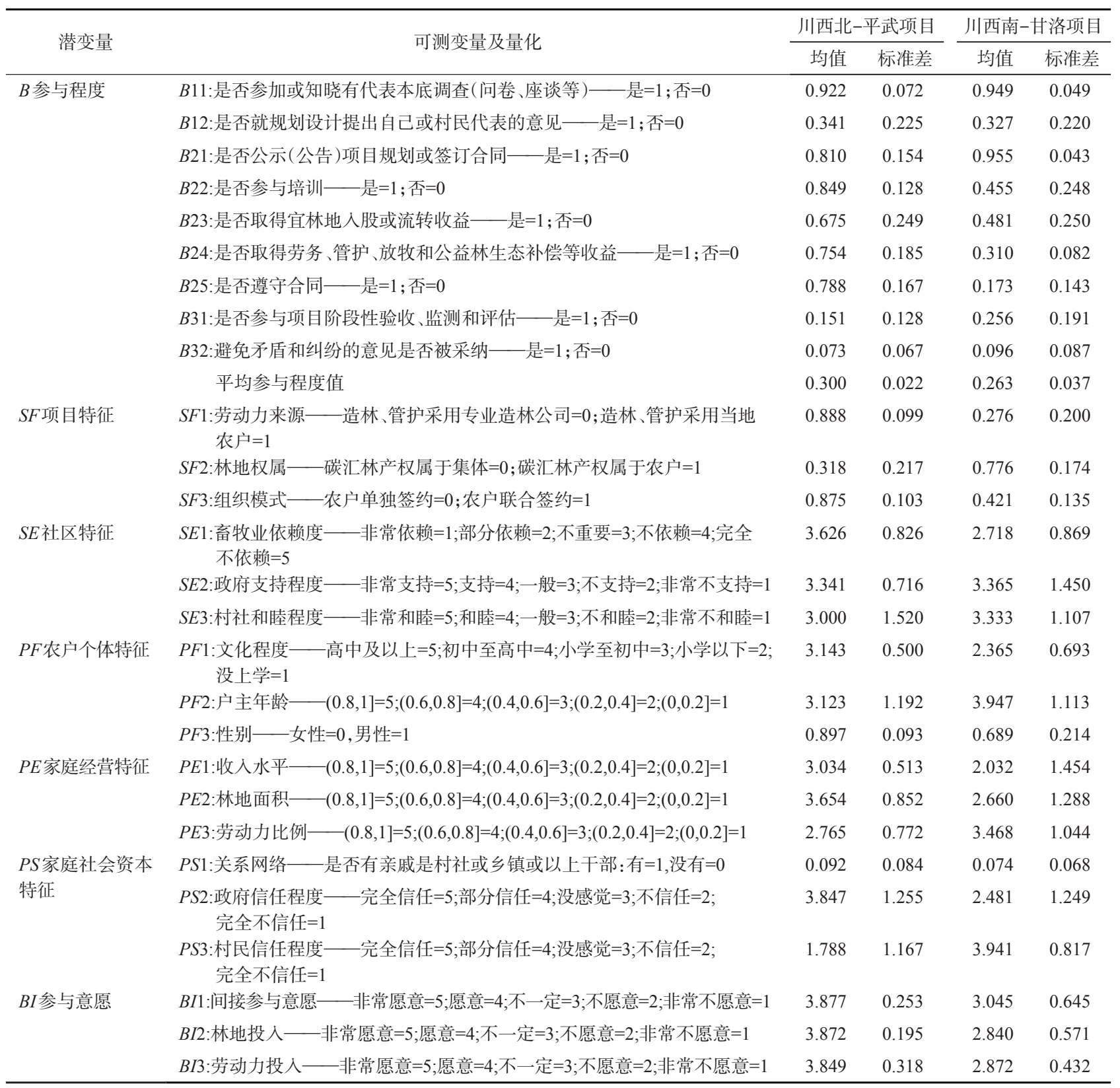

项目区在劳动力方面的参与率 $(0.3103)$ 低于川西 北-平武项目区 $(0.7542)$, 劳动力来源对参与程度的 影响也较高 $(0.9030)$ 。而川西北-平武项目的碳汇 林主要依赖于集体林地, 使得拥有承包经营权的农 户以林地人股、流转等方式参与项目的可行性降 低,因而林地投人方式是制约农户参与的很重要方 面, 对参与程度的边际影响较高 $(0.9880)$ 。此外, 从 签约模式来看,农户联合签约模式往往依托亲属关 系、邻里关系形成了非正式性组织,这些组织共同
拥有或具有决策权的碳汇林地占比较高, 且组织领 导者通常在村组具有一定的影响, 因而在树种选 择、林地经营、碳汇收益分配等方面更具有话语权 和知情权,森林碳汇项目的“主人翁意识”更强, 因 而配合程度越高。整体来看,一方面,劳动力和林 地投人是农户参与森林碳汇最为主要的方式,无论 是对哪一类参与的限制, 都会极大的减弱农户参与 性,因而在当前森林碳汇项目以政府推动为主的背 景下,增强农户在劳动力和林地投人上的自主性是 


\section{表 4 KMO 和 Bartlett 检验}

Table 4 KMO and Bartlett tests

\begin{tabular}{|c|c|c|c|c|c|}
\hline 一级指标 & 二级指标 & 标准因子载荷 & 有效因子数 & 克伦巴赫系数 & Bartlett \\
\hline \multirow[t]{3}{*}{$S F$ 项目特征 } & $S F 1$ :劳动力来源 & 0.607 & 1 & 0.572 & $242.483 * * *$ \\
\hline & $S F 2:$ 林地权属 & 0.741 & & & \\
\hline & $S F 3$ :组织模式 & 0.719 & & & \\
\hline \multirow[t]{2}{*}{$S E$ 社区特征 } & $S E 1$ :畜牧业依赖度 & 0.693 & 1 & 0.567 & $49.307 * * *$ \\
\hline & $S E 2$ :政府支持程度 & 0.743 & & & \\
\hline \multirow[t]{3}{*}{$P F$ 农户个体特征 } & $P F 1$ :文化程度 & 0.768 & 1 & 0.591 & $113.489 * * *$ \\
\hline & PF2:户主年龄 & 0.559 & & & \\
\hline & $P F 3$ :性别 & 0.534 & & & \\
\hline \multirow[t]{2}{*}{$P E$ 家庭经营特征 } & $P E 1$ :收人水平 & 0.572 & 1 & 0.491 & $63.480 * * *$ \\
\hline & PE2:林地面积 & 0.603 & & & \\
\hline PS家庭社会资本 & $P S 1$ :关系网络 & 0.733 & 1 & 0.542 & $57.361 * * *$ \\
\hline \multirow[t]{2}{*}{ 特征 } & PS2:政府信任程度 & 0.699 & & & \\
\hline & PS3:村民信任程度 & 0.807 & & & \\
\hline \multirow[t]{3}{*}{$B I$ 参与意愿 } & $B I 1$ :间接参与意愿 & 0.839 & 1 & 0.726 & $749.050 * * *$ \\
\hline & $B I 2$ :林地投人 & 0.908 & & & \\
\hline & $B I 3$ :劳动力投人 & 0.898 & & & \\
\hline \multirow[t]{8}{*}{$B$ 参与程度 } & B11:是否参加或知晓有代表本底调查(问卷、座谈等) & 0.684 & 1 & 0.572 & $285.764 * * *$ \\
\hline & $B 12$ :是否就规划设计提出自己或村民代表的意见 & 0.684 & & & \\
\hline & $B 21:$ 是否公示(公告)项目规划或签订合同 & 0.717 & & & \\
\hline & $B 22$ :是否参与培训 & 0.721 & & & \\
\hline & $B 23$ :是否取得宜林地人股或流转收益 & 0.754 & & & \\
\hline & B24:是否取得劳务、管护、放牧和公益林生态补偿等收益 & 0.677 & & & \\
\hline & B31:是否参与或知晓项目阶段性验收、监测和评估 & 0.725 & & & \\
\hline & B32:避免矛盾和纠纷的意见是否被采纳 & 0.693 & & & \\
\hline
\end{tabular}

注: ***表示在 $1 \%$ 置信水平下显著。

表 5 SEM 分析结果

Table 5 SEM analysis results

\begin{tabular}{|c|c|c|c|c|c|c|c|}
\hline 路径 & 模型 1 总模型 & 模型 2甘洛县 & 模型 3 平武县 & 路径 & 模型 1 总模型 & 模型 2 甘洛县 & 模型 3 平武县 \\
\hline$B \longleftarrow S F$ & $0.855^{* *}$ & $0.915^{* *}$ & $0.890 * *$ & $S E 1 \leftarrow S E$ & 0.892 & 0.903 & 0.317 \\
\hline$B \longleftarrow S E$ & $0.783 *$ & $0.866^{*}$ & $0.701 * *$ & $S E 2 \longleftarrow S E$ & 0.884 & 0.780 & 0.988 \\
\hline$B \leftarrow P F$ & $0.318^{*}$ & $0.357 * *$ & $0.291 *$ & $S E 3 \leftarrow S E$ & 0.687 & 0.538 & 0.718 \\
\hline$B \leftarrow P E$ & $0.297 *$ & $0.333 * *$ & $0.274 * *$ & $P F 1 \leftarrow P F$ & 0.875 & 0.801 & 0.863 \\
\hline$B \leftarrow P S$ & $0.757 * *$ & $0.743 * * *$ & $0.777 * *$ & $P F 2 \leftarrow P F$ & 0.886 & 0.839 & 0.894 \\
\hline$B \leftarrow B I$ & 0.357 & $0.277 * *$ & $0.197 * *$ & $P F 3 \leftarrow P F$ & 0.671 & 0.699 & 0.605 \\
\hline$B I \leftarrow S F$ & $0.494 *$ & $0.451 * *$ & $0.502 *$ & $P E 1 \leftarrow P E$ & 0.915 & 0.844 & 0.972 \\
\hline$B I \longleftarrow S E$ & $0.538^{*}$ & $0.687 * *$ & $0.494 *$ & $P E 2 \longleftarrow P E$ & 0.848 & 0.819 & 0.875 \\
\hline$B I \leftarrow P F$ & $0.535^{* *}$ & $0.570 * *$ & $0.505 * *$ & $P E 3 \leftarrow P E$ & 0.895 & 0.921 & 0.814 \\
\hline$B F \leftarrow P E$ & $0.511 * *$ & $0.483 * *$ & $0.512 * *$ & $P S 1 \leftarrow P S$ & 0.933 & 0.852 & 0.960 \\
\hline$B I \longleftarrow P S$ & $0.507 * *$ & $0.537^{*}$ & $0.495^{*}$ & $P S 2 \longleftarrow P S$ & 0.947 & 0.863 & 0.991 \\
\hline$S F 1 \leftarrow S F$ & 0.719 & 0.972 & 0.668 & $P S 3 \leftarrow P S$ & 0.959 & 0.936 & 0.978 \\
\hline$S F 2 \leftarrow S F$ & 0.734 & 0.683 & 0.899 & $B I 1 \leftarrow B I$ & 0.894 & 0.891 & 0.910 \\
\hline \multirow[t]{2}{*}{$S F 3 \leftarrow S F$} & 0.607 & 0.577 & 0.615 & $B I 2 \leftarrow B I$ & 0.816 & 0.855 & 0.738 \\
\hline & & & & $B I 3 \leftarrow B I$ & 0.870 & 0.894 & 0.841 \\
\hline
\end{tabular}

注: $* * *$ 和***分别表示在 $10 \% 、 5 \%$ 和 $1 \%$ 置信水平下显著。 
提升农户参与性的主要方面, 这就必然要求项目在 劳动力和林地等要素选择上的制度优化。另一方 面, 伴随着农地确权制度的深人和劳动力转移的增 加, 农户分化越发明显, 林地细碎化程度更高, 单个 农户参与到森林碳汇的可行性降低, 依托地方政府 或非正式组织进行联合签约, 是增强农户话语权和 建议权的主要方面,也能极大的改善农户对森林碳 汇的配合程度。

从社区特征来看, 川西南-甘洛为彝族集聚区, 对畜牧业依赖程度较大, 且牛、羊等畜牧品对于彝 民来说, 不仅仅是收人来源, 更具有地位象征、婚嫁 礼品等多重功能, 因而川西南-甘洛项目区林牧冲 突显著, 对参与程度影响高于川西北-平武项目区, 因而对畜牧业依赖程度对参与程度的边际贡献最 高 $(0.903)$ 。但从村社和睦程度来看, 由于川西北平武外出务工比例较高, 且属于多民族混合聚居 区, 村民之间日常交流较弱, 而川西南-甘洛以彝族 为主, 加上毕摩、宗族等非正式组织的存在, 村民之 间和睦程度较高, 在项目参与决策上同质性较大, 更有利于农户参与, 因而村民和睦程度对参与程度 的正向贡献高于平武项目区 $(0.988>0.780)$ 。无论 是川西北-平武项目还是川西南-甘洛项目区, 政府 的支持程度都是影响参与程度的主要因素, 这与目 前中国的基层治理结构相关, 同时,村委长期与村 民生活在一起, 建立起一定的信任关系, 相比于企 业而言, 政府更可信, 因而政府支持越高, 农户参与 程度越高。无论是已经开展的森林碳汇项目的发 展, 还是未来森林碳汇项目的开展, 基层组织始终 承担着重要的推动, 尤其是在当前农户分化日益明 显的形势下,依托基层组织优化森林碳汇发展环 境, 减少森林碳汇开展所带来的负面影响, 能极大 地提高农户对森林碳汇项目的支持。通过对比两 个项目区, 非正式组织在缓解社区环境对农户参与 上具有显著的作用。但值得关注的是, 非正式组织 在增强农户森林碳汇的话语权、建议权以及缓解社 区环境对农户森林碳汇参与制约等方面具有显著 地影响, 但不可否认的是非正式组织的功能有限, 尤其是近年来, 农村劳动力的大量外流, 导致农户 分化越来越明显, 以村两委为基础的基层治理体系 的完善也在一定程度上削弱了非正式组织的能力,
因而依赖非正式组织来增强农户参与的潜力不足。

此外,农户个体特征、家庭经营特征以及家庭 社会特征等自主因素也是影响农户参与程度的重 要方面, 尤其是家庭社会特征。中国农村的人口分 布, 目前仍然以同姓、亲属等关系为纽带,村民之间 大多具有直系或旁系亲属关系, 因而行为同质性较 强,关系网络越宽,与政府关系越密切的农户参与 程度越大。同时, 性别、文化程度、林地面积、收人 水平等也对参与程度具有显著的影响, 表明妇女、 少地者、收人低者等往往被边缘化,被排除在项目 参与之外。这不仅是因为不平等的政治博弯的存 在 ${ }^{[7]}$, 还因为妇女、少地者、收人低者往往不具备造 林、营林技术,且林地分散, 面积小, 森林碳汇项目 参与方式少,参与难度大。

\section{5 结论与建议}

\section{1 结论}

在政府推动的森林碳汇项目中, 农户参与程度 整体不高。

(1) 从制约因素来看, 项目特征和社区特征是 制约农户参与程度提升的主要方面, 项目特征主要 是通过强制性的项目契约限制农户劳动力和土地 投人的可能性,社区特征表现为群体性决策对农户 选择行为的影响以及区域发展对项目本身的制约 两个方面。家庭社会资本和物资资本以及家庭决 策的个体特征作为农户家庭资源禀赋的体现, 直接 决定着农户的“参与能力”, 因而也会影响参与程度 的高低。

(2)从要素视角来看, 农户参与主要是劳动力、 林地以及无形要素(建议、决策、选择等)三类要素 的投人,农户营林造林技术落后难以满足碳汇林建 设、林地准人标准严格限制大量林地资源投人、非 正式组织功能弱化而正式组织发展不足,是导致农 户参与程度较低的主要原因。

(3) 从政策启示来看, 提升农户参与程度的关 键在于增强农户在 3 类要素上的投人能力。劳动力 方面主要是农户现代林业经营技术的提升; 林地方 面主要是增强农户林地资源的可投人性,即林地标 准问题; 无形要素方面主要是推动正式组织发展, 发挥正式组织在增强农户话语权、建议权等方面参 与能力的作用。 


\section{2 建议}

在目前中国以政府为主推动林业碳汇项目的 背景下,建议从以下方面提升农户参与程度:

(1)农户维度: 关注农户劳动力投人能力的提 升。以政府为主导, 市场为辅助, 建立以造林、营林、 碳汇监测核算等实用技术为基础、注重实践操作的 基层教育机制, 提升有意愿参与森林碳汇的农户， 尤其是妇女、少地者、贫困户参与森林碳汇的能力。

(2) 项目维度: 关注农户林地投人能力的提 升。优化森林碳汇项目建设、监测标准, 在满足碳 汇计量监测标准的前提下, 尽量放宽对土地合格 性、树种等方面的限制, 增强农户林地要素投人上 的自主选择权,变换政府与农户在森林碳汇项目建 设中角色,发展“农户自愿+政府服务”的森林碳汇 开发模式。

(3) 政府维度: 关注农户无形要素投人能力提 升。着力推动林业股份合作社、林业专业合作社、 林业技术协会等林业类农民组织以及其他农民组 织的发展, 发挥农民组织在推动农户参与森林碳汇 建设、管理、监督等阶段的重要作用,条件成熟的地 区可以发展以森林碳汇为主要经营业务的林业类 合作社。

致谢: 感谢参与本文相关数据收集的老师和同学。 感谢四川农业大学漆雁斌教授、杨浩老师、张社梅 老师,西南科技大学庄天慧教授, 四川省社会科学院 张克俊教授在数据收集、文章撰写与修改上的帮助。

\section{参考文献(References):}

[1] 黄宰胜, 陈钦. 基于碳汇视角的碳汇林业发展对策分析[J]. 林业 经济, 2015, (11): 86-89. [ Huang Z S, Chen Q. The proposal analysis of carbon sequestration forestry based on carbon sequestration perspective[J]. Forestry Economics, 2015, (11): 86-89. ]

[2] 龚亚珍, 李怒云. 中国林业碳汇项目的需求分析与设计思路 [J]. 林业经济, 2006, (6): 36-38. [ Gong Y Z, Li N Y. Demand analysis and path design of China forest carbon sequestration[J]. Forestry Economics, 2006, (6): 36-38. ]

[3] 刘永富. 打好扶贫攻坚战全面建成小康社会 $[\mathrm{N}]$. 光明日报, 2014-10-17(10). [Liu Y F. Build a Well-Off Society and Build a Well- Off Society in an All- Round Way[N]. Guangming Daily, 2014-10-17(10). ]
[4] 曾维忠, 刘胜, 杨帆, 等. 扶贫视域下的森林碳汇研究综述[J]. 农 业经济问题, 2017, (2): 102-109. [ Zeng W Z, Liu S, Yang F, et al. A research review on poverty alleviation based on forest carbon sink projects[J]. Issues in Agricultural Economy, 2017, (2): 102109. ]

[5] 曾维忠, 张建羽, 杨帆. 森林碳汇扶贫: 理论探讨与现实思考 [J]. 农村经济, 2016, (5): 17-22. [ Zeng W Z, Zhang J Y, Yang F. Forest carbon sequestration poverty alleviation: theoretical discussion and practical thinking[J]. Rural Economy, 2016, (5): 17-22. ]

[6] Perez C, Roncoli C, Neely C, et al. Can carbon sequestration markets benefit low-income producers in semi- arid Africa? Potentials and challenges[J]. Agricultural Systems, 2007, 94(1): 2-12.

[7] Cacho O J, Marshall G R, Milne M. Transaction and abatement costs of carbon-sink projects in developing countries[J]. Environment and Development Economics, 2005, 10(5): 597-614.

[8] 明辉, 漆雁斌, 李阳明, 等. 林农有参与林业碳汇项目的意愿吗以 CDM 林业碳汇试点项目为例[J]. 农业技术经济, 2015, (7): 102-113. [Min H, Qi Y B, Li Y M, et al. Does the forest farmers have the desire to participate in the forestry carbon sequestration project-taking CDM forestry carbon sequestration pilot project as an example[J]. Journal of Agrotechnical Economics, 2015, (7): 102-113. ]

[9] 杨帆, 曾维忠, 张维康, 等. 林农森林碳汇项目持续参与意愿及 其影响因素[J]. 林业科学, 2016, 52(7): 138-147. [ Yang F, Zeng W Z, Zhang W K, et al. Foresters' constant participation willingness and affecting factors in forest carbon sequestration project[J]. Scientia Silvae Sinicae, 2016, 52(7): 138-147. ]

[10] 王昭琪. 农户参与林业碳汇意愿及影响因素动态分析-以云南 省凤庆县、镇康县为例 [J]. 中国林业经济, 2014, (5): 75-78. [Wang Z Q. Dynamic analysis on the farmers' willingness to participate in forestry carbon sequestration and influencing factorstaking Fengqing and Zhenkang in Yunnan as an example[J]. China Forestry Economics, 2014, (5): 75-78. ]

[11] 宁可, 沈月琴, 朱臻. 农户对森林碳汇认知及碳汇林经营意愿分 析-基于浙江、江西、福建 3 省农户调查[J]. 北京林业大学学报 (社会科学版), 2014, 13(2): 63-69. [ Ning K, Shen Y Q, Zhu Z. Analysis of rural households' cognition and management willingness of forest carbon sequestration: surveys of rural households in Zhejiang, Jiangxi and Fujian Provinces[J]. Journal of Beijing Forestry University(Social Sciencs), 2014, 13(2): 63-69. ]

[12] Benessaiah K. Carbon and livelihoods in Post-Kyoto: assessing voluntary carbon markets[J]. Ecological Economics, 2012, 77(3): 1-6.

[13] Antle J M, Stoorvogel J J. Payments for ecosystem services, poverty and sustainability: the case of agricultural soil carbon sequestration [J]. Springer New York, 2009, 31: 133-161.

[14] Benitez P, McCallum I, Obersteiner M, et al. Global Supply for Carbon Sequestration: Identifying Least- Cost Afforestation Site 
Sunder Country Risk Considerations[R]. Laxenbur: II A-SA, IR04-022, 2004

[15] Nhung N T H. Optimal Forest Management for Carbon Sequestration: A Case Study of Eucalyptus Urophylla and Acacia Mangium in Yen Bai Province, Vietnam[R]. Singapore: EEPSEA Final Report, 2009.

[16] 朱臻, 沈月琴, 吴伟光, 等. 碳汇目标下农户森林经营最优决策 及碳汇供给能力-基于浙江和江西两省调查[J]. 生态学报, 2013, 33(8): 2577-2585. [ Zhu Z, Shen Y Q, Wu W G, et al. Household optimal forest management decision and carbon supply: Case from Zhejiang and Jiangxi Provinces[J]. Acta Ecologica Sinica, 2013, 33(8): 2577-2585. ]

[17] 陈冲影. 森林碳汇与农户生计-以全球第一个森林碳汇项目为 例[J]. 世界林业研究, 2010, 23(5): 15-19. [Chen C Y. Forestry carbon sequestration and local households' livelihoods: taking the first CDM forestry carbon project in the world as example[J]. World Forestry Research, 2010, 23(5): 15-19. ]

[18] 丁一, 马盼盼. 森林碳汇与川西少数民族地区经济发展研究以四川省凉山彝族自治州平武县为例[J]. 农村经济, 2013, (5): 38-41. [Ding Y, Ma P P. The forest carbon sink and Sichuan economic development of minority areas in Yuexi County, Sichuan Yi Autonomous Prefecture, Liangshan Province as an example[J]. Rural Economy, 2013, (5): 38-41. ]

[19] 黄颖利, 聂佳. 林农参与森林碳汇行为意向理论分析框架-基 于 TPB 模型的视角[J]. 经济师, 2013, (11): 24-25. [ Huang Y L, Nie J. The theoretical analysis framework of forest farmers' participation in forest carbon sequestration-based on the perspective of TPB model[J]. China Economist, 2013, (11): 24-25. ]
[20] 乐章, 涂丽. 农村基层自治组织功能与农民政治参与程度-基 于十省农户调查数据实证分析 [J]. 经济与管理, 2015, 29(2): 23-28. [Le Z, Tu L. Rural grassroots autonomous organizations' function and farmers' political participation-an empirical analysis based on the farmers' survey data of 10 provinces[J]. Economy and Management, 2015, 29(2): 23-28. ]

[21] 黄祖辉, 刘西川, 程恩江. 贫困地区农户正规信贷市场低参与程 度的经验解释[J]. 经济研究, 2009, (4): 116-128. [Huang Z H, Liu X C, Cheng E J. Explanations for the low participation rate in the formal credit market by rural households in the poor areas[J]. Economic Research Journal, 2009, (4): 116-128. ]

[22] 郭瑜. 需求与现实: 农民工养老保险参与程度的影响因素分 析-基于 7 城市数据的考察[J]. 农业技术经济, 2010, (11): 3745. [ Guo Y. Requirements and reality: endowment insurance participation and impact factors for rural migrant workers-inspection based on data from 7 cities[J]. Journal of Agrotechnical Economics, 2010, (11): 37-45. ]

[23] 汪文雄, 王文玲, 朱欣, 等. 农地整理项目实施阶段农户参与程 度的影响因素研究[J]. 中国土地科学, 2013, (7): 62-68. [ Wang W X, Wang W L, Zhu X, et al. Impact factors on the willingness of farmers participating in farmland consolidation planning[J]. China Land Sciences, 2013, (7): 62-68. ]

[24] 何钊, 王秀兰, 文高辉, 等. 城乡建设用地增减挂钩项目农户参 与程度及其影响因素研究 [J]. 水土保持研究, 2016, 23(4): 233238. [He Z, Wang X L, Wen G H, et al. Factors influencing rural households participation degree in linkage between urban-land and rural-land giving area[J]. Research of Soil and Water Conversation, 2016, 23(4): 233-238. ] 


\title{
Factors restricting the participation of farmers in Forest Carbon Sequestration Projects
}

\author{
GONG Rongfa ${ }^{1}$, ZENG Weizhong ${ }^{1,2}$ \\ (1. College of Economics, Sichuan Agricultural University, Chengdu 611130, China; \\ 2. Southwest Center for Poverty Alleviation and Development Research, Chengdu 611130, China)
}

\begin{abstract}
Forest Carbon Sequestration Projects(Afforestation and reforestation project under the Clean Development Mechanism) driven by government in Sichuan Province as samples and using Structural Equation Model, we researched the factors that restrict the farmers' participation on the basis of Embedded Social Structure Theory. The results of the study show that there are three important reasons leading to low degree of farmers' participation. Firstly, It is difficult to meet the strict requirements of the construction of carbon sequestration forest because of the backwardness of afforestation technology of farmers; And then, firm admittance criterion of forest land makes the forest land which many households have the right of contracted management can not be included in the Forest Carbon Sequestration Project. Finaly, there are no demonstration organizations that can drive the households to participate in Forest Carbon Sequestration Project because of weakening of the function of the informal organization and insufficient development of the formal organization in the community. Therefore, there are three important measures to increase the degree of farmers' participation. Improving farmers' afforestation and forestation technology by carrying out technical training, reducing forest land access standards by optimizing the organization structure of Forest Carbon Sequestration Project, and promoting the development of community organizations such as forestry cooperatives. At the same time, Resource endowment such as the area of forest land, the structure of family labors and the level of income, and social capital such as the relationship network, the degree of trust of the government and the degree of trust of the villagers also affect farmers' willingness and abilities to participate in Forest Carbon Sequestration Projects to a certain extent, although almost all of the forest carbon sequestration projects are now driven by the government.
\end{abstract}

Key words: Forest Carbon Sequestration Project; participation degree; Embedded Social Structure Theory; Structural Equation Modeling 